\title{
The role of lipids in controlling microbial growth
}

\author{
By Tim F. Brocklehurst and Peter D.G. Wilson \\ Institute of Food Research Norwich Research Park Colney \\ NORWICH NR4 7UA, UK.
}

\section{RESUMEN \\ El papel de los lípidos en el control del crecimiento microbiano}

Numerosos alimentos son, o contienen, emulsiones. El crecimiento de bacterias en las emulsiones da lugar a alteraciones debido a bacterias, levaduras, mohos o bacterias que producen intoxicaciones alimentarias. En los alimentos constituidos por dos fases (por ejemplo emulsiones aceite-agua 0 agua-aceite) la estructura del alimento puede influir tanto en el ritmo de crecimiento como en las condiciones en las que se inicia el crecimiento. El lugar en el que se encuentran los microorganismos es la fase acuosa. Y, por tanto, es la composición química de esta la que influye directamente en la supervivencia y el crecimiento de los microorganismos. En esta contribución se describe el efecto de los ácidos orgánicos utilizados como conservantes en las emulsiones aceite-agua (ácidos acético y lácticos) y en las de agua-aceite (ácidos sórbico y benzoicos) así como la influencia de sus estructuras en la estabilidad del alimento.

PALABRAS-CLAVE: Alimento (estabilidad) - Conservantes - Crecimiento microbiano - Emulsiones.

\section{SUMMARY}

The role of lipids in controlling microbial growth

Many foods are, or contain, emulsions. Growth of microorganisms in emulsions may lend to spoilage by bacteria, yeasts, moulds or food-poisoning bacteria. In biphasic foods (e.g. oil-in-water or water-in-oil emulsions), food structure may influence both rate of growth and conditions under which growth is initiated. The site of occupancy of microorganisms is the aqueous phase. Therefore the chemical composition of this phase is what has a direct influence on the survival and growth of microorganisms. This paper describes the chemical effects of organic acids used as preservatives in oil-in-water (acetic and lactic acids) and water-in-oil (sorbic and benzoic acids) emulsions as well as the influence of their structures on the food stability.

KEY-WORDS: Emulsions - Food (stability) - Microbial growth - Preservatives.

\section{INTRODUCTION}

Many foods are, or contain, emulsions. Typically, the emulsions are oil-in-water (such as milk, dairy cream or mayonnaise) or water-in-oil (such as butter or low fat spread), although multiple emulsions (e.g. water-in-oil-in-water) are being introduced. In foods, the volume of each phase varies, as does the droplet size distribution, although the mean value is usually between narrow limits (Table I).

Table I

Typical characteristics of food emulsions. (Compiled from data in Brocklehurst and Lund, 1984; Tunaley et al., 1985; Ranken, 1988; Macrae. et al., 1993; Buehheim. and Dejmek, 1997).

\begin{tabular}{clcc}
\hline Emulsion type & \multicolumn{1}{c}{ Product } & $\begin{array}{c}\text { Typical lipid } \\
\text { concentration }(\% \mathrm{v} / \mathrm{v})\end{array}$ & $\begin{array}{c}\text { Typical droplet } \\
\text { diameter }(\mu \mathrm{m})\end{array}$ \\
\hline Oil-in-Water & Mayonnaise & $28-85$ & $1-8$ \\
& Salad cream & 25 & $1-5$ \\
& Milk & $3-4$ & 3 \\
& Cream liqueur & 16 & 0.15 \\
& Dairy cream & $12-60$ & 3 \\
\hline Water-in-Oil & Butter & $80-84$ & $1-30$ \\
& Margarine & 80 & 1 \\
& Low fat spread & 40 & $0.1-10$ \\
\hline
\end{tabular}

Growth of micro-organisms in emulsions may lead to spoilage due to the production of gas or taints by bacteria or yeasts, or to visible colonial growth of bacteria, yeasts or moulds on the surface of the product. Some food emulsions can support the growth of food-poisoning bacteria and although their growth is often accompanied by the growth of spoilage micro-organisms, and obvious visible spoilage, this is not always so.

Historically, food microbiology has assumed that, within the food matrix, it is the chemistry alone that controls the growth of micro-organisms. The experimental basis of this paradigm was the growth of micro-organisms in liquid culture medium. The assumption was then made that the organisms would grow similarly in the liquid culture medium as they would in foods of an equivalent chemical composition, but this approach ignores any effect of structure of the food on microbial growth 
(Brocklehurst et al., 1993; Robins and Wilson, 1994; Robins et al., 1994).

In biphasic foods, the lipid component may have a controlling influence on microbial growth through its contribution to the structure of the growth domain of the micro-organisms, and its contribution to the redistribution of chemical components between the phases of the foods, and it is these features that are discussed here.

\section{CHEMICAL EFFECTS}

The site of occupancy of micro-organisms in emulsions is the aqueous phase (Tuynenburg Muys, 1971; Brocklehurst et al., 1995), and hence it is the chemical composition of this phase that has a direct influence on the survival and growth of bacteria, yeasts and moulds.

Oil-in-water food emulsions such as salad creams and mayonnaises rely heavily for their preservation on the concentration of organic acids, such as acetic acid or lactic acid, which are added to the product partly for organoleptic purposes. These and water-in-oil emulsions such as margarines or low-fat-spreads sometimes also contain sorbic acid or benzoic acid, which are added specifically as preservatives. In addition, the concentration of sugars or salts can contribute to preservation, as will be described later. The organic acid components interact with the lipid phase, however, and the effect is a decrease in the preservation of the products.

\section{ORGANIC ACIDS}

Acetic, lactic and sorbic acid (and its salts) (Figure 1) are amongst the most widely used antimicrobial food additives. They may be added to foods deliberately, although acetic and lactic acids are also produced in fermented foods as endproducts of microbial metabolism. By virtue of their effect on the $\mathrm{pH}$ of the food and the antimicrobial properties of the undissociated form of the molecule, these acids inhibit the growth and metabolism of a wide range of pathogenic and spoilage micro-organisms. The target concentration of acetic and lactic acids found in foods is a balance between the effects of the acids on the organoleptic properties of the food, and the concentration of acids required for their antimicrobial activity. Sorbic acid has a neutral taste and odour and the acid and its salts are permitted widely in foods in the USA, where they have "Generally Recognised As Safe" (GRAS) status, although their use in the UK is restricted by statute (Anon, 1979).<smiles>CC(O)C(=O)O</smiles><smiles>CC(=O)O</smiles>

Lactic acid

Acetic acid<smiles>C[C]=CC=CC(=O)O</smiles>

Sorbic acid

Figure 1

Structural chemical formulae for acetic, lactic and sorbic acids.

The antimicrobial efficacy of organic acids is affected by the fundamental thermodynamic characteristics of dissociation and partition. However, these characteristics of the acids are also key to an understanding of the controlling effect of the lipid phase of emulsions on the growth of micro-organisms, and are described below.

\section{DISSOCIATION}

This is the characteristic of a chemical compound to separate into certain component parts. In the case of weak acids, such as acetic and sorbic acids, it is an ionization reaction.

A general equation for compounds that dissociate by ionization in this way is:

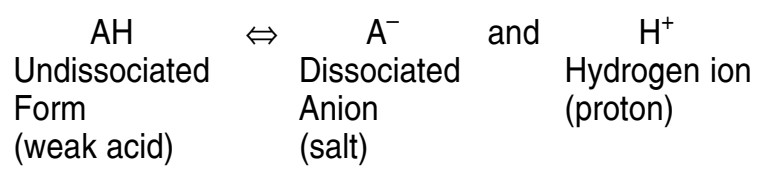

For example, acetic acid dissociates according to the equation:

$$
\begin{aligned}
& \underset{\text { Acetic acid }}{\text { (undissociated) }_{3} \mathrm{COOH}}
\end{aligned} \Leftrightarrow \begin{aligned}
& \begin{array}{l}
\text { Acetate } \\
\text { (dissociated) }
\end{array} \\
& \mathrm{CH}_{3} \mathrm{COO}^{-}
\end{aligned} \text {and } \begin{aligned}
& \text { Hydrogen ion } \\
& \text { (proton) }
\end{aligned}
$$

The dissociation is an equilibrium, and the concentration of each side of the equilibrium equation is dictated by the dissociation constant (or $\mathrm{Ka}$ ) that is a characteristic of the compound, thus:

\section{Equation 1}

$$
K_{a}=\frac{[\text { anion }]\left[\mathrm{H}^{+}\right]}{[\text {undissociated acid }]}
$$

So, in the case of acetic acid it is the ratio, thus: 
Equation 2

$$
K_{a}=\frac{[\text { acetate }]\left[\mathrm{H}^{+}\right]}{[\text {acetic acid }]}
$$

The values of $\mathrm{K}_{\mathrm{a}}$ for acetic acid and sorbic acid at $25^{\circ} \mathrm{C}$ are identical at $1.76 \times 10^{-5}$ moles/litre (Windholz, 1983), and the $\mathrm{K}_{\mathrm{a}}$ of lactic acid is $1.37 \mathrm{x}$ 10-4 (Windholz, 1983) (Table II).

The dissociation constant is a cumbersome small value, and, for convenience, is often expressed in the form of its negative logarithm and given the term $\mathrm{pK}_{\mathrm{a}}$ :

\section{Equation 3}

$$
K_{a}=-\log \left(K_{a}\right)
$$

so that a $\mathrm{K}_{\mathrm{a}}$ of $1.76 \times 10^{-5}$ moles/litre (acetic acid and sorbic acid) becomes a $\mathrm{pK}_{\mathrm{a}}$ of 4.76 , and $\mathrm{a} \mathrm{K}$ 积 $1.37 \times 10^{-4}$ (lactic acid) becomes a $\mathrm{pK}_{\mathrm{a}}$ of 3.86 .

Table II

\section{Published values for dissociation constants and $\mathrm{pK}_{\mathrm{a}}$ values for organic acids commonly

\begin{tabular}{|c|c|c|}
\hline Organic acid & $\begin{array}{l}\text { Dissociation constant } \\
\left.\text { at } 25^{\circ} \mathrm{C} \text { (moles litre }-1\right)\end{array}$ & $\mathrm{pK}_{\mathrm{a}}$ at $25^{\circ} \mathrm{C}$ \\
\hline Acetic & $1.76 \times 10^{-5}$ & 4.76 \\
\hline Lactic & $1.37 \times 10^{-4}$ & 3.86 \\
\hline Benzoic & $6.46 \times 10^{-5}$ & 4.20 \\
\hline Sorbic & $1.73 \times 10^{-5}$ & 4.76 \\
\hline
\end{tabular} used as preservatives in emulsion foods.}

The $\mathrm{pK}_{\mathrm{a}}$ varies with temperature, but only slightly, and an empirical equation which describes this variation for a number of weak acids is:

\section{Equation 4}

$$
p K_{a}=\left(\frac{A}{T}\right)-B+(C T)
$$

Where $T$ is the temperature in degrees Kelvin $\left({ }^{\circ} \mathrm{K}\right)$, and $\mathrm{A}, \mathrm{B}$ and $\mathrm{C}$ are shown in Table III.
Table III

Values of $A, B$ and $C$ to be inserted into Equation 6 for calculation of the effect of temperature on $\mathrm{pK}_{\mathrm{a}}$ (Robinson and Stokes, 1959).

\begin{tabular}{rccc}
\hline Acid & A & B & C \\
\hline Acetic & 1170.48 & 3.1649 & 0.013399 \\
Lactic & 1286.49 & 4.8607 & 0.014776 \\
Benzoic & 1590.2 & 6.394 & 0.01765 \\
\hline
\end{tabular}

Dissociation is important in the preservation of emulsion foods because the preservatives that undergo these reactions are usually more active in one form than the other. It is the undissociated form that has the predominant antimicrobial effect in foods (Baird-Parker, 1980; Sofos and Busta, 1981; Eklund, 1983), and hence it is the concentration of this form that is important in the formulation of foods that rely on these acids as the preservative.

For any given concentration of these acids in foods a proportion exists as the acidic undissociated form, and a proportion as the dissociated anionic form (See Equation 1 and Equation 2). When the $\mathrm{pH}$ of a food is equivalent to the $\mathrm{pK}_{\mathrm{a}}$, the proportions of the acid and its salt are equal. If the $\mathrm{pH}$ of the food is decreased, then the concentration of the undissociated form is increased. If the $\mathrm{pH}$ of the food increases, however, the concentration of the undissociated form declines.

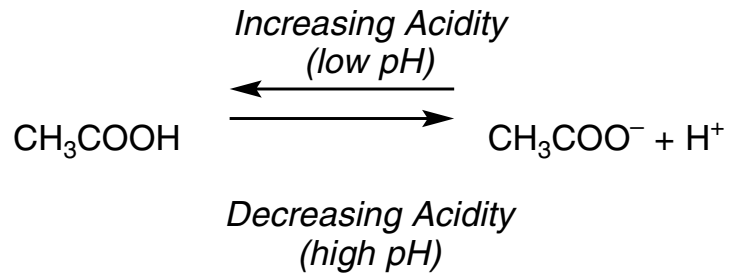

The Henderson-Hasselbalch equation (Equation 5) derives directly from the definition of $\mathrm{pK}_{\mathrm{a}}$, and relates the $\mathrm{pH}$ of the food to the $\mathrm{pK}_{\mathrm{a}}$ and the relative proportions of dissociated and undissociated acid, thus:

\section{Equation 5}

$$
p H=p K+\log _{10} \frac{\text { [dissociated acid] }}{\text { [undissociated acid] }}
$$


This may be rearranged to give the concentration of weak acid in its undissociated (i.e. microbiologically active) form, $[\mathrm{HA}]_{\mathrm{aq}}$, given the $\mathrm{pH}, \mathrm{pK}_{\mathrm{a}}$, and total weak acid concentration, $[\mathrm{HA}]_{\mathrm{T}}$, as follows:

\section{Equation 6}

$$
[\mathrm{HA}]_{\mathrm{aq}}=\frac{[\mathrm{HA}]_{\mathrm{T}}}{1+10\left(p H-p K_{\mathrm{a}}\right)}
$$

Using this equation and a $\mathrm{pK}_{\mathrm{a}}$ of $4.76\left(25^{\circ} \mathrm{C}\right)$ in the case of acetic acid, the effect of $\mathrm{pH}$ on the proportion of the dissociated and undissociated antimicrobial forms is shown in Figure 2.

For example, in a food where the total concentration of acetic acid or lactic acid is $1.5 \%(\mathrm{w} / \mathrm{v})$, the actual concentration of the antimicrobial undissociated form changes as shown in Table IV.

Table IV

Effect of pH on the actual concentration of acetic acid present in the undissociated form, when the total concentration of acetic acid remains at $1.5 \%(w / v)$.

\begin{tabular}{lc}
\hline $\mathrm{pH}$ & $\begin{array}{c}\text { Concentration }(\% \mathrm{w} / \mathrm{v}) \\
\text { of undissociated acetic acid }\end{array}$ \\
\hline 3.0 & 1.47 \\
3.5 & 1.42 \\
4.0 & 1.28 \\
4.2 & 1.18 \\
4.4 & 1.04 \\
4.6 & 0.89 \\
4.76 & 0.75 \\
4.8 & 0.72 \\
5.0 & 0.55 \\
5.2 & 0.40 \\
5.4 & 0.28 \\
5.6 & 0.19 \\
6.0 & 0.08 \\
6.5 & 0.03 \\
7.0 & 0.01 \\
\hline & \\
\hline
\end{tabular}

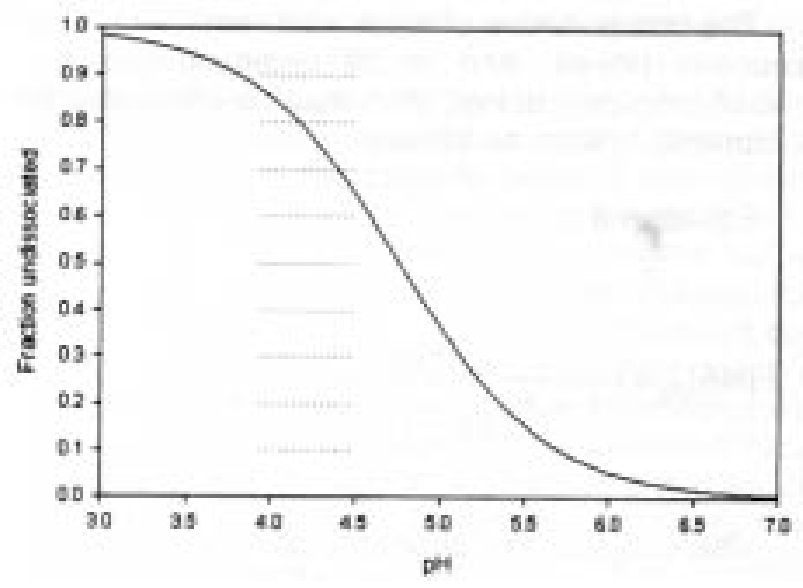

Figure 2

Effect of $\mathrm{pH}$ on the proportion of acetic acid that is undissociated and dissociated.

\section{PARTITION}

The lipid component of biphasic foods is key in controlling the concentration of undissociated antimicrobial compounds in the aqueous phase. This is because the antimicrobial undissociated form of organic acids is lipophilic, partitions between the aqueous and lipid components of foods (Gordon and Reid, 1922; Bodansky, 1928; von Schelhorn, 1964; Leo et al., 1971), and hence decreases the concentration of undissociated acid in the aqueous phase. The aqueous phase of many foods, however, contains a range of solutes, often added for organoleptic purposes, or, as in the case of $\mathrm{NaCl}$ and sucrose, to decrease the water activity of the food in order to increase its preservation. However, the movement of undissociated organic acids into the lipid phase of biphasic foods can be increased by the addition of solutes to the aqueous phase (Gooding et al., 1955; Sofos and Busta, 1981). This further decreases the concentration of the effective form of the antimicrobial in the aqueous phase. In many foods the concentration of acetic, lactic and sorbic acid is poised to the minimum required for conferring microbiological stability and so any decrease in this concentration due to partition into the lipid phase can allow micro-organisms to grow.

The oil:water partition coefficient $(\mathrm{Kp})$ is the ratio of the concentration of a compound in the lipid phase to its concentration in the aqueous phase. So, for the case of the undissociated weak acid moiety, HA, we have:

\section{Equation 7}

$$
K_{p}=\frac{[\mathrm{HA}]_{\mathrm{oil}}}{[\mathrm{HA}]_{\mathrm{aq}}}
$$


The concentration of weak acid remaining in the aqueous phase, and in its undissociated (i.e. microbiologically active) form may be calculated for a biphasic system as follows:

\section{Equation 8}

$$
[\mathrm{HA}]_{\mathrm{aq}}=\frac{[\mathrm{HA}]_{\mathrm{T}}}{1+K_{p}\left(\frac{\phi}{1-\phi}\right)+10^{\left(p H-p K_{a}\right)}}
$$

where $\mathrm{K}_{\mathrm{p}}$ is the apparent partition coefficient between the aqueous phase and the oil of interest, and $\phi$ is the volume fraction of oil in the dispersion, given by:

\section{Equation 9}

$$
\phi=\frac{V_{\text {oil }}}{V_{\text {aqueous }}+V_{\text {oil }}}
$$

where $V_{\text {oil }}$ and $V_{a q}$ are the volumes of oil and aqueous phases respectively.

\section{Table V}

Published values for partition coefficients of organic acids commonly used to preserve food emulsions.

\begin{tabular}{cc}
\hline Organic acid & Lipid: water partition coefficient \\
\hline Acetic & $0.03-0.07$ \\
Benzoic & $6-13$ \\
Sorbic & 3.1 \\
\hline
\end{tabular}

Part of the value of acetic acid as an antimicrobial agent in multiphase foods is due to its low partition coefficient. This means that only a very small proportion of it is dissolved in the lipid phase, and it is therefore predominantly available in the water phase as a preservative. This is not the case for the deliberately-added preservatives such as sorbic acid and benzoic acid, however, where the controlling effect of the lipid phase on their distribution is greater. These acids have a relatively large partition coefficient, and so a large proportion of their total concentration in the emulsion is in the lipid phase, and hence unavailable in the aqueous phase.

Prediction of partition based on published data is difficult, however. Many partition coefficients are determined between model alkanes (e.g. octane) and water (Table V), and comparison of empirically determined partition coefficients between a lipid phase and water show that partition coefficients determined in an alkane (hexadecane):water system are often a poor guide to the value of partition coefficients in a food lipid (sunflower oil):water system (Table VI).

Table VI

The partition coefficients of acids in a hexadecane: water system and in a sunflower oil: water system

\begin{tabular}{ccc}
\hline \multirow{2}{*}{ Acid } & \multicolumn{2}{c}{ Partition coefficient in } \\
Sunflower oil:water \\
Acetic & $0.03-0.08$ & 0.02 \\
Sorbic & 0.08 & 2.15 \\
Lactic & 0.0 & 0.033 \\
\hline
\end{tabular}

The hexadecane:water partition coefficient and the sunflower oil:water partition coefficient for these preservatives increased when solutes were added to the aqueous phase (Table VII), at concentrations typical of those found in acid-preserved foods, such as mayonnaise (Brocklehurst and Lund, 1984).

Table VII

The effect of solutes in the water phase on the partition coefficient in a two-phase system.

\begin{tabular}{clllll}
\hline Non-polar phase & Acid & No solutes & $10 \%(\mathrm{w} / \mathrm{v})$ NaCl & $40 \%(\mathrm{w} / \mathrm{v})$ Sucrose & Both \\
\hline Hexadecane & Acetic & 0.02 & 0.10 & 0.62 & 0.89 \\
& Sorbic & 0.08 & 0.47 & 0.47 & 0.88 \\
\hline Sunflower oil & Acetic & 0.02 & 0.08 & 1.15 & 1.36 \\
& Sorbic & 2.15 & 4.99 & 2.87 & 5.84 \\
\hline
\end{tabular}


(Strictly, if the partition coefficient is defined in terms of the thermodynamic activity of the weak acid rather than the more easily measured concentration, then there would be no effect of additional dissolved solutes on the partition coefficient. The effect observed on the concentration of weak acid is merely a reflection of the dissolved solutes changing the activity of the weak acids.)

Typically, the methodology for determination of partition coefficients involves poising the $\mathrm{pH}$ of the system sufficiently low to ensure that the acids are present in the undissociated form, and measuring the residual aqueous phase concentration after equilibrating with a known amount of the oil of interest.

The $\mathrm{pH}$ of biphasic foods, however, is typically in a region where weak organic acids are present in both the undissociated and the dissociated form. This makes calculation of the residual concentration of the undissociated form of the acid following partition difficult, as the concentration itself is subject not only to the effects of partition, but to the equilibrium of dissociation based on the new $\mathrm{pH}$ of the system and the new residual concentration of the undissociated acid. Such calculations require a more complex approach coupling the equations for dissociation and partition with the buffering behaviour of the complex systems encountered in foods. For a fuller discussion of these issues, see Wilson et al, 2000.

\section{THE EFFECTS OF STRUCTURE}

\section{Oil-in-water emulsions}

As well as the dairy emulsions such as milk or cream, these also include the "manufactured» emulsions such as salad creams and mayonnaises, where the manufacturer has some control over formulation of the product.

In addition to the effects of the lipid component on the composition of the aqueous phase as described above, the lipid phase imposes structure on these emulsions, and this can affect the form of growth of bacteria, their rate of growth, and the habitat domain in which growth occurs.

In oil-in-water food emulsions the oil phase is present as polydisperse droplets that typically have a mean diameter of between 1 and 8 micrometers (Table I), which means that, in concentrated emulsions, the space of the interstices between the droplets is of the same order of size. This is also the same order of size as many bacteria, which varies between approximately 0.4-1.5 $\times$ 0.5-5 micrometers in the case of rod-shaped bacteria or approximately 0.5-2 micrometers in diameter in the case of cocci. In model emulsions where the concentration of lipid phase was low $(30 \% \mathrm{v} / \mathrm{v})$ the growth of bacteria was as free-living (or planktonic) cells. An increase in the concentration of lipid had no effect on the form of growth of bacteria until the lipid content increased to $83 \%(\mathrm{v} / \mathrm{v})$, when the bacteria became immobilised between the oil droplets. The structure imposed by the lipid phase caused the bacteria to grow not as planktonic cells, but as discrete colonies. Visualisation of micro-organisms within emulsions is difficult due to the opacity of the droplets. However, using a chloroform:methanol solvent system Brocklehurst et al. (1995) and Parker et al. (1995) examined these colonies in situ (Figure 3), and showed that as the colonies formed from a single bacterium they expanded by displacing the emulsion droplets, although eventually the constraint of crowding of the lipid phase caused the colony to grow around some of the droplets (Figure 3).

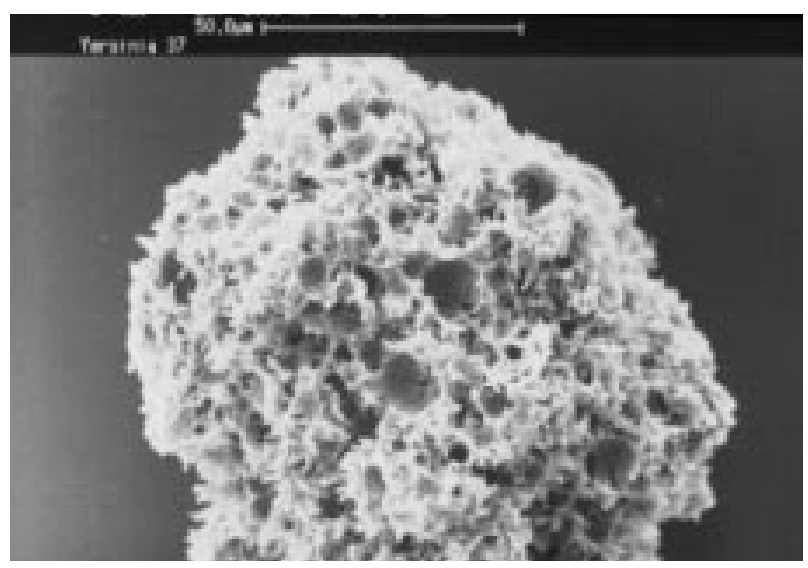

Figure 3

An electron photomicrograph of a colony of Yersinia enterocolitica which has grown from a single bacterium during incubation of an emulsion that had a lipid phase of $83 \%$ (v/v) for 72 hours at $20^{\circ} \mathrm{C}$. Photomicrograph was prepared by Dr Mary Parker of the Institute of Food Research. It first appeared in Brocklehurst et al. (1995), and is used by kind permission of Blackwell Science Ltd

The effect of immobilisation of the bacteria by the lipid component was a decreased rate of growth and a shrinkage of the habitat domain compared with growth as planktonic cells. Shrinkage of the habitat domain means that the conditions of $\mathrm{pH}$ and water activity that are required for the initiation of growth of immobilised bacteria are higher than for planktonic culture, and hence immobilisation by the lipid phase can contribute to preservation of food emulsions.

\section{Water-in-oil emulsions}

These include margarines and low-fat spreads. The emulsions consist of an internal aqueous phase 
dispersed as discrete spherical or irregularlyshaped droplets (which, in the case of margarines, range between 0.3 and 30 microns in diameter (Verrips and Zaalberg, 1980; Charteris, 1995) within the external continuous oil phase, which may contain crystallised fats.

Water-in-oil food emulsions can be contaminated with micro-organisms at the point of manufacture (Verrips and Zaalberg, 1980), and these will be isolated within the droplets of the aqueous phase. The proportion of droplets occupied by microorganisms is small, and is a function of the initial contamination, and the numbers of droplets exceeding the minimum size for occupancy (Verrips and Zaalberg, 1980; Charteris, 1995).

The micro-organisms metabolise the carbon sources within the droplets, and classical theories to describe microbial growth rely on the droplets remaining as discrete compartmentalised structures, which limit the availability of water, space and nutrients for growth. The microbiological stability of these emulsions is enhanced, therefore, when the droplet size is small, and the controlling effect of lipid in these emulsions is to maintain a distribution of discrete droplets separated from one another, such that if microbial growth occurs in one droplet, it is limited in its extent, and the majority of the aqueous phase remains unaffected in sterile droplets. Based on these assumptions, the models of Verrips and Zaalberg (1980) and Verrips et al. (1980) can be used mechanistically to predict the potential for growth of bacteria within discrete droplets of known dimensions when the growth and energy demands of the contaminating bacteria are known (Ter Steeg et al., 1995). These models show that bacterial growth and survival can be limited when the emulsion structure remains intact, and when coalescence of the droplets does not occur.

In the new generation of low fat spreads, a large volume of dispersed aqueous phase is contained within a small volume of lipid phase, and instability due to coalescence is a key challenge to the manufacture of these products. Coalescence may be spontaneous in inherently unstable emulsions, but can occur in parallel with microbial growth in otherwise stable emulsions, and experiments in model experimental water-in-oil emulsions, which had a fluid lipid phase, showed that an increase in numbers of bacteria was always accompanied by coalescence of the droplets of aqueous phase (Brocklehurst et al., 1993). This is an example of where the controlling effect of a solidified lipid phase was removed.

Although the bacteria in the droplets can grow well, their numbers remain small when expressed per unit volume of emulsion, although their local number density within a droplet is extremely high. Normally, micro-organisms cease to grow when the concentration of end-products of metabolism, typically organic acids, produced during growth becomes toxic or if a requirement for growth, such as oxygen or a carbon source, is exhausted. However, the lipid phase of emulsions could decrease the concentration of organic acid within the aqueous phase by partition, as described above, and this may contribute significantly to high local numbers of bacteria within droplets.

\section{REFERENCES}

Anon, (1979). Statutory Instrument No. 752. Food and Drugs Composition and Labelling. The Preservatives in Food Regulations 1979. HMSO. London, UK.

Baird-parker, A.C. (1980). Organic acids. In Microbial ecology of foods. Vol 1. Factors affecting life and death of micro-organisms, by the International Commission on Microbiological Specifications for Foods, pp. 126-135. New York, Academic Press.

Bodansky, M. (1928). Lipoid solubility, permeability and hemolytic action of the saturated fatty acids. Journal of Biological Chemistry 79, 241-255.

Brocklehurst, T.F. Parker, M.L., Gunning, P.A. and Robins, M.M. (1993). Microbiology of food emulsions: physicochemical aspects. Lipid Technology 5(4), 8388.

Brocklehurst, T.F., Parker, M.L., Gunning, P.A., Coleman, H.P. \& Robins, M.M. (1995). Growth of food-borne pathogenic bacteria in oil-in-water emulsions: II Effect of emulsion structure on growth parameters and form of growth. Journal of Applied Bacteriology 78, 609615.

Brocklehurst, T.F. and Lund, B.M. (1984). Microbiological changes in mayonnaise-based salads during storage. Food Microbiology 1, 5-12.

Buehheim, W. and Dejmek, P., (1997), «Milk and Dairy-Type Emulsions", In: Friberg, S.E. and Larsson,

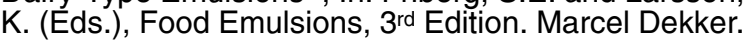
New York, USA.

Charteris, W.P. (1995) Physicochemical aspects of the microbiology of edible table spreads. Journal of the Society of Dairy Technology 48 (3) 87-96.

Eklund, T. (1983). The antimicrobial effects of dissociated and undissociated sorbic acid at different $\mathrm{pH}$ levels. Journal of Applied Bacteriology 54, 383-389.

Gooding, C.M., Melnick, D., Lawrence, R.L. and Luckmann, F.H. (1955). Sorbic acid as a fungistatic agent for foods. IX. Physicochemical considerations in using sorbic acid to protect foods. Food Research 20, 639-648.

Gordon, N.E. and Reid, E.E. (1922). The solubility of liquids in liquids. The partition of the lower acids, particularly formic, between water and various organic solvents. Journal of Physical Chemistry 26, 773-789.

Leo, A., Hansch, C. and Elkins, D. (1971). Partition coefficients and their uses. Chemical Reviews 71, 525631.

Macrae, R., Robinson, R.K., and Sadler, M.J. (1993). Encyclopaedia of Food Science, Food Technology and Nutrition. Academic Press. London, UK.

Parker, M.L., Brocklehurst, T.F., Gunning, P.A., Coleman, H.P. \& Robins, M.M. (1995). Growth of food-borne pathogenic bacteria in oil-in-water emulsions: I Methods for investigating the form of growth of bacteria in 
model oil-in-water emulsions and dairy cream. Journal of Applied Bacteriology 78, 601-608.

Ranken, M.D. (1988). Food Industries Manual, 22nd edn. Glasgow and London, Blackie.

Robins, M.R. and Wilson, P.D.G. (1994). Food Structure and Microbial Growth. Trends in Food Science and Technology Today 5, 289-293.

Robins, M.M., Brocklehurst, T.F., \& Wilson, P.D.G. (1994). Food structure and the growth of pathogenic bacteria. Food Technology International Europe, pp. 31-36.

Robinson, R.A. and Stokes, R.H. (1959). Electrolyte solutions. London, Butterworths.

Sofos, J.N. and Busta, F.F. (1981). Antimicrobial activity of sorbate. Journal of Food Protection 44, 614-622 + 647.

Ter Steeg, P.F., Pieterman, F.H and Hellemons, J.C (1995) Effects of air/nitrogen, temperature and $\mathrm{pH}$ on energy-dependent growth and survival of Listeria innocua in continuous culture and water-in-oil emulsions. Food Microbiology 12, 471-485.

Tunaley, A., Brownsey, G, and Brocklehurst, T.F. (1985). Changes in mayonnaise-based salads during storage. Lebensm.-Wiss. u. Technol. 18, 220-224.
Tuynenburg Muys, G. (1971) Microbial safety in emulsions. Process Biochemistry 6 (6), 25-28.

Verrips, C.T., Smid, D. and Kerkhof, A. (1980). The intrinsic microbial stability of water-in-oil emulsions II. Experimental. European Journal of Applied Microbiology and Biotechnology 10, 73-85.

Verrips, C.T. and Zaalberg, J. (1980). The intrinsic microbial stability of water-in-oil emulsions I. Theory. European Journal of Applied Microbiology and Biotechnology 10, 187-196.

Von Schelhorn, M. (1964). Distribution of preservatives between fat and water in foods. In Microbial inhibitors in food. Proceedings of the Fourth International Symposium on Food Microbiology, Göteborg, Sweden. Stockholm, Göteborg, Uppsala, Almquist \& Wiksell.

Wilson, P.D.G., Wilson, D.R. and Waspe, C.R. (2000). Weak acids: dissociation in complex buffering systems and partitioning into oils. J. Sci. Food Agric. (In press)

Windholz, M. (1983). The Merck Index. Rahway, Merck and Co Inc. 